ECONOMICS

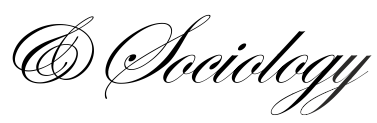

Vasilyeva, T., Bagmet, K., Bilan, S., \& Seliga R. (2020). Institutional development gap in the social sector: cross-country analysis. Economics and Sociology, 13(1), 271294. doi:10.14254/2071-789X.2020/13-1/17

\title{
INSTITUTIONAL DEVELOPMENT GAP IN THE SOCIAL SECTOR: CROSS- COUNTRY ANALYSIS
}

\author{
Tetyana Vasilyeva \\ Sumy State University, \\ Sumy, Ukraine \\ E-mail: \\ tavasilyeva@fem.sumdu.edu.ua

\section{Svitlana Bilan \\ Rzeszón University of Technology, Poland \\ E-mail:s.bilan@prz.edu.pl \\ ORCID 0000-0001-9814-5459}

\section{Kseniya Bagmet \\ Sumy State University, \\ Sumy, Ukraine} \\ E-mail: kbagmet2017@gmail.com

\section{Robert Seliga} \\ University of Social Sciences, \\ Poland \\ E-mail:rseliga@san.edu.pl \\ ORCID 0000-0003-3306-904X
}

Received: September, 2019

1st Revision: December, 2019

Accepted: February, 2020

DOI: $10.14254 / 2071-$

789X.2020/13-1/17

JEL Classification: I38, I39, C21

\begin{abstract}
An institutional quality convergence is always a relevant subject matter since institutional quality is considered to be a vital factor for economic development. The question regarding the convergence of social parameters into development is especially acute when choosing a social policy direction and the related instruments. This paper proposes a methodology to calculate the institutional development gap of social sector (IDGSS) in its three measures: social capital development, social infrastructure development, social security system development. IDGSS is calculated here for 20 countries. The estimation demonstrates how social development parameters (social capital, social infrastructure and social security) depends on a country's economic development level. Besides, we show how IDGSS depends on noneconomic factors, including the level of basic institutions' development, the degree of inequality in the distribution of income and poverty.
\end{abstract}

Keywords: institutions, convergence, IDGSS, social capital, social infrastructure, social security

\section{Introduction}

Both theoretical and empirical studies confirm the fact that institutions are essential for economic growth. Acemoglu (2009) claimed that "there is convincing empirical support for the assumption that differences in economic institutions, more than luck, geography or 
culture, cause differences in incomes per capita". However, economic growth is being reconsidered today. Economic growth has ceased to be recognized as the only objective of economic policy. The key task now is to build a sustainable development model. Among five pillars of SDGs (people, prosperity, planet, peace and partnership), "people and prosperity" take the first positions. Therefore, the issue of improving the social environment quality is among the top objectives of any contemporary economic policy. When studying the social sector institutions, we assume that their development should be closer directed towards better quality institutions since globalization processes involve the approximation of social and economic development parameters in different countries. The enlargement of the European Union also implies a convergence of the related institutions. However, for effective regulation of social development processes, it is important to understand the existing gaps in institutional quality, social infrastructure, etc.

\section{Literature review}

The issue of convergence in economic literature usually arises while studying the convergence trends the countries at the level of GDP per capita. At the same time, recognition of the fact that institutional quality defines economic development has prompted some authors to study the convergence of institutions as well. In particular, Savoia and Sen (2012) stated that "if the institutional quality is a crucial determinant of economic growth, we need a better understanding of how institutions evolve and under what circumstances they change. One step in this direction is to ask whether we observe convergence in institutions such as low-income countries with poor quality institutions and the best practice institutions that are prevalent in the richer countries“. Savoia and Sen (2012) obtained the confirmation of conditional and unconditional convergence of institutional quality, including legal, administrative and bureaucratic components, as well as the contract environment quality and the protection of private property rights. Moreover, their results are valid for both developed and transition economies.

Institutional convergence between Central and Eastern European countries was explored by Gruševaja and Pusch (2015) following the EU norms. These authors found no confirmation for institutional convergence between the countries of this group, except for the first years of transition.

Balcerzak et al. (2015) also explored convergence in the development aspect of EU countries. They assumed that the convergence of EU countries takes place under the knowledge-based economy. They also concluded that the convergence depends on the institutional quality according to the conditions of the knowledge-based economy.

La Porta et al. (2008) supposed that institutional quality convergence is the result of the globalization impact, emerging in faster exchange of ideas and growing competition between countries for foreign direct investment.

López-Tamayo et al. (2014) analyzed the convergence of macroeconomic, institutional and social conditions for EU countries using a composite indicator. They concluded that there is conditional convergence between EU countries, but unconditional convergence is not fully confirmed.

Antonescu (2014) examined regional convergence. Among other factors that influence it, he identified social factors (quantity and quality of labour force, entrepreneurship, RDI activity, the politically unstable environment, skilled labour force migration from less developed regions to the developed one). Harshad, (2017a) (2017b) studied the role of institutions in the context of social progress. Social issues and institutional development factors have become particularly relevant while exploring the prerequisites to achieve the SDGs of the United Nations. Thus, Kostel, et al., (2017) investigated the impact of 
institutions on the achievement of SDGs for the Eastern Partnership countries. Bhandari and Bhattarai, (2017) analyzed which institutional architecture is necessary to achieve sustainable development in Asian countries. Iacobuta et al., (2019) examined the relationship between institutional quality and sustainable development according to economic, social and environmental aspects. Three measures of sustainable development were taken into account by GDP per capita for the economic measure, the Human Development Index for the social measure, and World Governance Indicators analyze the environmental quality for the ecological measure, the institutional quality of countries. Institutional aspects to ensure an adequate level of remuneration in the context of achieving sustainable development were studied by Melnyk et al., (2017). Vargas-Hernández et al., (2018) analyzed institutional capital and environmentally sustainable development under NAFTA. When examining the issues of inequality in the development of Lithuanian regions, Maknickienè et al., (2018) raised the problem of policy formation that would let to achieve the regional development convergence for this country. In the study of the local convergence, the methodology of a quantitative assessment of the regional development sustainability based on multicriteria assessment methods, proposed by Ginevicius, R. (2019), attracted attention.

Yevdokimov et al., (2018) analyzed basic institutions - economic freedom and democracy as determinant factors in increasing macroeconomic stability. Bilan et al., (2018a,b), Sokolenko et al., (2018), Grenčíková et al., (2019), Kolosok and Myroshnychenko, (2015), Vasilyeva et al., (2019), Mentel et al., (2018), Bilan et al., (2019a), Vasilyeva et al., (2014) represented institutions as a factor of macroeconomic stability, business cycle dynamics and sustainable economic development in developing countries and transition economies. In this problem, the role of institutions in the development of the financial and investment markets of transition economies, studied by Djalilov et al., (2015), Dovhan et al., (2017), Poliakh et al., (2017), Leonov et al., (2012), Kostyuchenko et al., (2018), Leonov et al., (2014), Valaskova et al., (2018), Vasilyeva et al., (2013), Bilan et al., (2019b), Vasilyevaet al., (2014), arouses great interest.

James E. Austin et al. (2007), Gowdy et al., (2009), Buriak et al., (2019), Brychko and Semenog, (2018), Bilan et al., (2019c), Kliestik et al., (2018) supposed that the convergence of social development parameters is relevant today for two reasons: 1) The growing importance of social issues and the necessity to bring countries closer to social standards; 2) Blurring the boundaries between the commercial and social sectors.

Ravallion (2012), who analyzed and confirmed slow convergence in income distribution, but does not prove poverty convergence, is among researchers of social parameter convergence. The author explained the situation by the initial poverty level, which complicates the achievement of some proportional impact of growth on poverty reduction. Ravallion (2012) made the important assumption "The initial level of poverty may well be picking up other factors, such as the distribution of human and physical capital; indeed, the underlying theories point to economic poverty rather than consumption or income poverty". It precisely helps find supporting points for economic policy.

Canning, (2012) studied the convergence of health across countries. The result of his research confirmed the average life expectancy convergence in different countries. Many countries achieved progress in healthcare without a considerable increase in income.

Andrés and Tselios (2013) examined convergence in social welfare for 15 EU countries. The results of their research showed that despite the lack of convergence in GDP per capita, welfare levels have significantly converged across European regions. An essential finding of this study confirmed the link between social welfare convergence, institutional convergence and convergence of other structural factors.

Niroomand and Nissan, (2007), Migala-Warchol \& Pasternak-Malicka, (2018) found the convergence of social parameters of development particularly relevant in choosing the 
direction and social policy tools. Smirnov et al., (2019) investigated the convergence of the socio-economic security indicator in the municipalities of Latvia and its constituents.

It is important to evaluate the state of things in the development of specific components in the social sector (Sulkowski et.al., 2019b). This issue is especially relevant for countries in the process of creating a new model of the social sector (Sulkowski et.al., 2019a). Ko \& Min, (2019) investigated the development of the welfare state by comparing the Western capitalist countries and the post-socialist countries of Asia and Europe by examining the determinants of social expenses. However, this study alone is not sufficiently representative due to cost dynamics. Therefore, continuing the series of studies of the institutional quality and the factors that form it by Bilan et al. (2019), Vasilyeva et al., (2018), we assess the level of the development gap between social sector institutions in Europe. We consider it an early stage of a deeper study of the institutional convergence of the social sector.

The following studies should further solve the question, how do social sector institutions influence economic progress? Where is the impetus for transforming the economic model and achieving better development? In order to solve the problem of how the functioning of one country's social sector is better and more progressive than of the others, we propose to evaluate the social sector institutional development gap. Bazo et al., (2019) applied a close approach to the study of the "difference" of institutional conditions in the economy, exploring the Institutional Hysteresis Effect in the context of the institutional environment impact on Slovak enterprises.

Ginevichius et al., (2018) emphasized the necessity for the quantitative and qualitative development of socio-economic systems. Moreover, quantitative development indicates the level of system development at some point in time, while qualitative development indicates the scale of its changes. These aspects should be quantified and combined into one generalized indicator to make a comprehensive assessment regarding the state of development of these systems.

The dynamics of the IDGSS can indicate the existence or absence of convergence in social sector development between countries.

In this paper, we also aim to assess how the parameters of social development (social capital, social infrastructure and social security) depend on the country's economic development level.

\section{Methodological approach}

We propose the model demonstrated in Figure 1 to formalize the social sector institutional development gap and to analyze the factors that define it.

The institutional development area of an individual country will be evaluated using the social sector institutional development index and it will be defined by three measures: development of social capital, development of social infrastructure, development of social security system.

Social capital is the most important measure of institutional development in the social sector. The emergence of this concept changed approaches to its definition. Initially, social capital was seen as a resource that enables to realize the individuals' interests in their interaction (Baker, W. 1990). At present, social capital is the ability of people to work together for common goals (Fukuyama, 1995).

Modern approaches defining social capital emphasize its institutional nature and complex social, economic and cultural nature. Fukuyama, (1995) defined it as a set of informal rules and norms that are established between people and allow them to interact. 


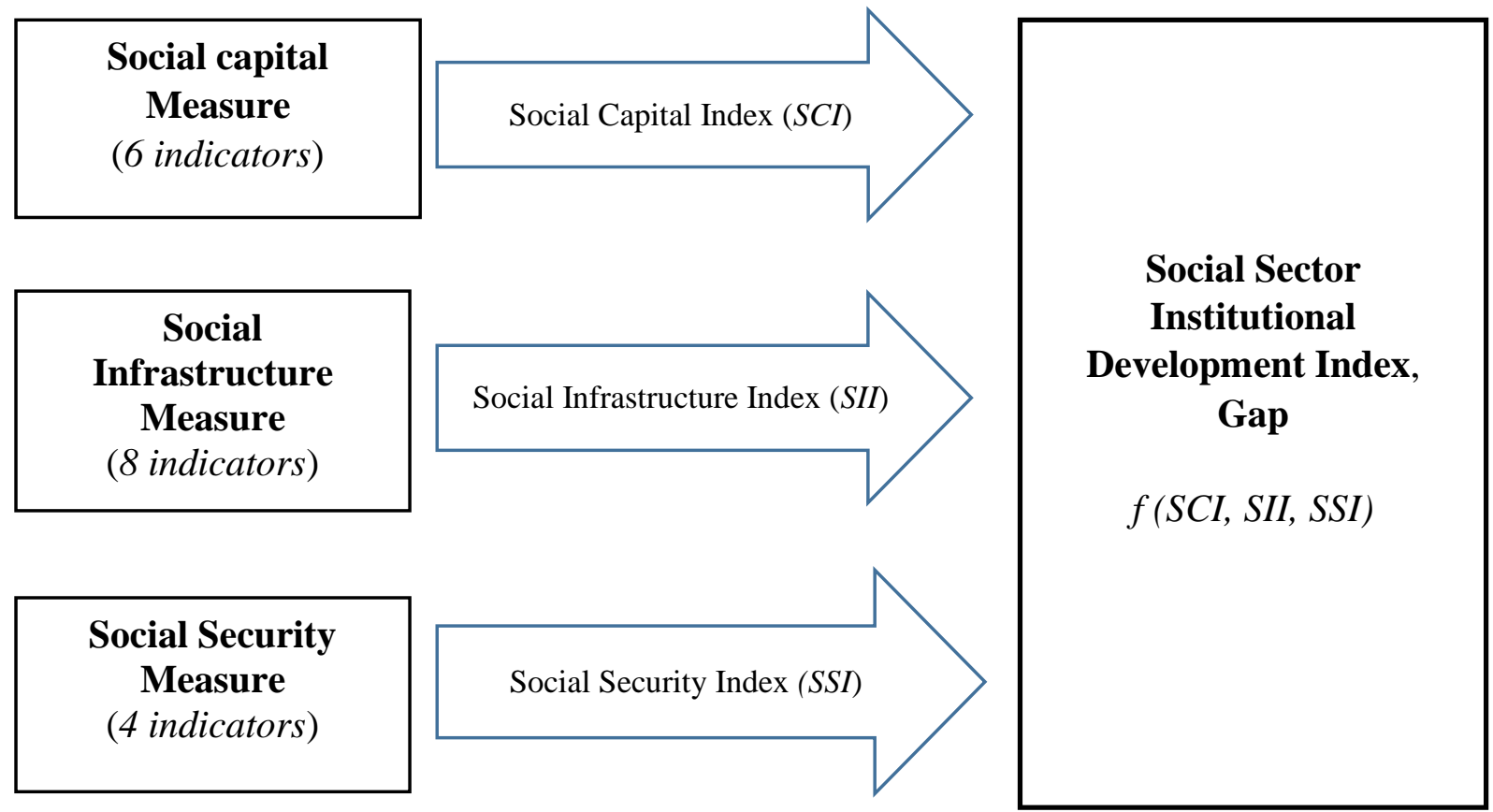

Figure 1. The model of the social sector institutional development gap

Source: Own elaboration

Inglehart (1997: 188) defined social capital as "a culture of trust and tolerance in which extensive networks of voluntary associations emerge". Sadiqi, (2018) considered social capital as a factor of communities development.

The definition of social capital is complicated, along with its measurement. Claridge, (2004) studied the genesis of measuring social capital that has been used by various scholars for empirical research. The basic measures of social capital are networks of social relations (structures), formed on the principles of trust and reciprocity. Thus, today, the best tools for measuring social capital are based on the outcomes of its main components (related to its core components (networks, trust and reciprocity). Skačkauskienė \& Bytautė, (2012) analyzed the link between social capital and economic development.

Social capital issues are also explored at the organizational level. Thus, Abu-Hamour, (2018) examined such aspects of the social capital organization as employee engagement, ascertaining that it promotes employees' perceptions of methods for improving work, creates strong relationships between employees, values and the organization. Khorakian, Jahangir, (2018) investigated the innovative behaviour and its impact on the social network among employees as an aspect of social capital development. Shpak, (2017) also explored the social direction of enterprises' innovation activity.

In this study, we use the Indices of social development, proposed by the research team of the International Institute for Social Studies with technical and financial support from the World Bank, as indicators of social capital development. The parameters from 25 reputable data sources ensure the development of indices by six measures of social progress: Civic Activism, Clubs and Associations, Intergroup Cohesion, Interpersonal Safety and Trust, Gender Equality, Inclusion of Minorities.

These measures allow, first, to evaluate the development of informal social institutions that enable individuals maximum to use their skills and resources to enable them to live fullon lives. Second, to track global progress in building and supporting social institutions that contribute to the well-being of people. Third, to compare the parameters of social capital development in different countries and to determine the peculiarities and parameters of their convergence. 
Today, social capital plays an essential role as a development factor. In particular, Bausch, (2019) examined whether social capital defines fiscal cyclicality. The study confirms the strong feedbacks between social capital and pro-cyclicality. From the author's point of view, these relationships are partly realized through the adoption of fiscal rules and the corruption level.

The issue of social capital is explored in various areas of functioning of organizations, in particular, Veri et al., (2019) explored the formation of good relationships within the team as a factor of productivity.

Another measure of institutional development is social infrastructure.

Social infrastructure, as a part of assets providing social services, has a positive impact on economic growth and social development. The growth of social support generates many explicit and implicit effects, and therefore it is difficult to evaluate them. Over the last two decades, studies have identified the positive impact of investing in the social sphere, developing public-private partnerships and other forms of investing in social infrastructure. The calculations showed that net income from investing in preschool education exceeds investment by 2-2.6 times; pre-K programs give $\$ 11$ per $\$ 1$ of investment. Health infrastructure development reduces the difference in Healthy Life Expectancy (HLE) for different social classes, reducing cases of severe limiting long-term illness (LLTI), reducing mortality rates, reducing crime, increasing employment opportunities. (Northern Ireland Assembly, 2017). Such positives contribute to enhance trust, law and order, stability and social well being through community support; security. It means that the development of social infrastructure ensures social capital development. (Casey S., 2005).

Investigating the health protection system for 25 European countries, Pacáková \& Kopecká, (2018) form a synthetic variable based on 16 indices to monitor health inequalities. The obtained results were compared with the results of the self-assessment of the health state provided by citizens of the same countries. The results of this comparison showed significant similarities between assessment statuses and objectively measured health states.

Within the framework of social infrastructure, we also analyze the indicators that describe the education system (Annex 1), since education today is an extremely significant element of the social sector and the economy as a whole. Tvaronavičienè et al., (2018) analyze education systems from a sustainable development point of view, in particular how education systems can increase economic, innovation and business potential and contribute to sustainable economic development. The analysis of educational policy was studied concerning the realities of social and political alienation and economic marginalization. Hitka et al., (2018) investigated the relationship between education and gender, based on the selected motivation factors. The results of the study confirmed the hypothesis that there are significant differences in the motivation factors among Slovak employees related to their gender and education. Humbatova and Hajiyev, (2019) examined how education funding affected quality indicators and confirmed a positive relationship between distribution.

Menshikov and Volkova, (2018) investigated the availability of medical care in Latvia. They determined the availability of health care by two factors - economic growth and institutional development. The result of the research proposed that it is necessary not only to ensure economic growth but to develop institutions to increase the availability of health care services since their effective interaction contributes to improving the quality of the citizens' life.

The third measure of social development space is social security. Every society must protect its citizens in case of a life-threatening event. Under these circumstances, a person cannot effectively exercise his or her abilities and needs help in the form of minimal income or assistance in restoring his or her ability to work. The social security systems of different countries, their construction, the parameters of coverage of the population with the programs 
of compensation, rehabilitation and prevention determine the effectiveness of their functioning. Mishchuk et al., (2019) propose a method which identifies distributive mechanisms in the context of social justice.

Halaskova, (2018) examined social policy trends through the structure of national expenditures on social security and identified differences in types of social security, in particular, a significant difference between the Scandinavian countries compared to the Eastern European and Baltic states. However, there are no confirmations of differences between the expenditures groups for social security for all EU Member States with similar social models. It explains the differences between the spending levels of countries by different standards of welfare, differences in social protection systems, demographic trends, unemployment rates and other social, institutional and economic factors. Cyrek, (2019) studied the effectiveness of state social expenditures to reduce poverty and income inequalities in the EU countries and identified differences in government effectiveness in the observed countries. Generally, countries with higher levels of social spending are less efficient. Negative changes in the current use of funds lead to this situation. However, Cyrek, (2019) noted that institutional reforms have a positive impact on the effectiveness of social expenditures.

We consider social security in the labour market particularly important in the social security system since it ensures the economic well-being stability and resistance to shocks. An effective social security system in the labour market is the key to achieving equality for all categories of the working population. This issue is especially essential in the context of demographic change, namely the ageing of the community. Žofčinová, (2017) noted that the population ageing determines social security. It applies not only to European countries. In particular, Oh et al., (2017) studied the development of human capital - middle-aged workers to ensure a stable life and reduce the financial burden of business. They solve this problem through the development of the education system - the formation of training programs that promote the development of middle-aged human resources. Cho and Lee, (2018) explored the use of human capital and employment in Korea, including the causes of university graduates' employment decline, proposing a range of activities related to changes in study programs (university level), changes by employer companies and changes in state employment policy.

Lewandowska-Gwarda, (2018) studied women's unemployment and what role social factors play in it and identified the most critical factors for Poland in spatial terms. Dmytrów \& Bieszk-Stolorz, (2019) analyzed the relationship between the unemployment rate and length of unemployment in Visegrad countries. Kobylińska et al., (2017) analyzed youth unemployment in the context of education. It is a comprehensive study that links youth employment and educational development. The obtained results show that education is not such a factor that employs since the graduates do not have the appropriate qualifications and the required level of practical training. Novák et al., (2016), on the contrary, called education quality a topical issue, making employment policies ineffective for the least qualified unemployed. Novák et al., (2016), on the contrary, called the current issue an issue for the Czech Republic for the quality of education that makes employment policies ineffective for the least qualified unemployed. Mursa, (2018) examines employment among economies in EU countries, including the UK. Their results showed that countries that pay more attention to education and vocational training, promote youth employment, are the most effective at reducing youth unemployment, and their real GDP per capita is increasing.

Dirzyte et al., (2017) investigated the inequality, but not in the context of social or fiscal policy, but through the development of social culture and education. The analysis of the socio-economic vulnerability factors revealed statistically significant differences in the resilience of different income groups. These social security aspects are essential. Still, the 
study did not include these indicators due to the lack of statistic data for the observed countries.

Therefore, it is necessary to investigate the quality of social sector development based on indicators characterizing various aspects of its functioning. We propose to evaluate the impact of each factor using a corresponding index, which integrally takes into account the value of a set of indicators for each measure of the social sector institutional development. The list of indices, included in each parameter, is given in Annex 1. We will reduce indicators which have different physical measures and calculated indices to a normalized form so that they vary from 0 to 1 , to ensure their comparability. In this case, the best values will be close to 1 .

In this work, we will not pay much attention to each indicator included in the corresponding index. Therefore, we consider their specific weightings equal.

The proposed method of analysis assumes that the institutional development of the country's social sector is integrally evaluated by the Social Sector Institutional Development Index (SSIDI) within three indices. (Figure 2)

This index is a vector, the norm of which determines the level of the social sector institutional development of the country, and its spatial position in the coordinate system (SCI, SII, SSI), respectively, describes the relative level of the social sector institutional development. The equidistance of the SSIDI vector from each of the coordinates will correspond to the highest growth of each component of the country's social sector institutional development.

Approximation of this vector to one of the coordinates will indicate a greater level of development of this component in the institutional development of the social sector than other.

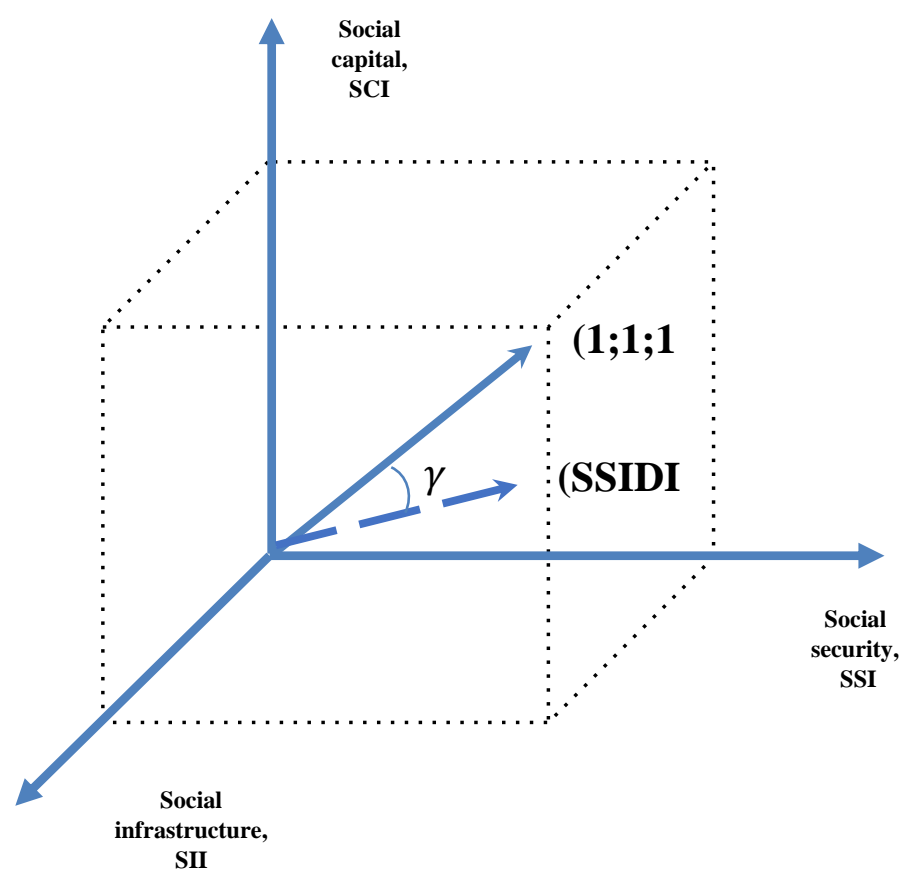

Figure 2. Social sector institutional development Gap of the country Source: Own elaboration

This measure estimates the social sector institutional development gap, which determines the level of Institutional Development Parity of Social Sector in a country of three measures (social capital, social infrastructure, social security). 
(Social sector institutional development gap $\gamma_{j}$ is calculated as an angle between a vector $S S I D I_{j}$ and norm

where $\mathrm{j}$ - country,

$$
\left\|S S I D I_{j}\right\|=\sqrt{\left(S C I_{j}^{2}+S I I_{j}^{2}+S S I_{j}^{2}\right)}
$$

and "ideal" vector with the norm

$$
\|1\|=\sqrt{\left(1^{2}+1^{2}+1^{2}\right)}
$$

This angle is measured in degrees and is calculated by the formula:

$$
\begin{gathered}
\gamma_{j}=\arccos \frac{S C I_{j}+S I I_{j}+S S I_{j}}{\sqrt{3} \sqrt{\left(S C I_{j}^{2}+S I I_{j}^{2}+S S I_{j}^{2}\right)}} \\
0 \leq \gamma_{j} \leq \arccos \arccos \left(\frac{1}{\sqrt{3}}\right)
\end{gathered}
$$

The smaller the $\gamma$, the smaller the gap and, accordingly, the greater Institutional Development Parity of Social Sector.

Besides, the calculated values of $\gamma_{j}$ for different countries can be compared by setting a country with a minimum amount of the social sector institutional development gap. This indicator characterizes the relative gap in the Comparative IDGSS.

One of the essential ways of using the proposed methodology is to use data to the obtained indices, which determine it, and to compare them with the average values of indicators by countries, taking into account the level of their economic development.

\section{Conducting research and results}

For analysis, we have compiled a database of the proposed 19 indicators of the social sector development of countries, divided by three measures for 20 nations. The countries were divided into four groups to analyze the impact of the level of economic development of countries on the balance of institutional development of the social sector and the size. Group I includes the economically developed countries of Europe, which are in G7 (France, Germany, Italy, United Kingdom). Group II includes economically developed countries, members of EU except for Turkey (Austria, Belgium, Denmark, Finland, Netherlands, Portugal, Sweden, Turkey). Group III comprises the New EU Member States (Estonia, Latvia, Lithuania, Romania). Group IV comprises post-Soviet republics (Armenia, Georgia, Russian Federation, Ukraine).

The calculation results of the IDGSS by countries are demonstrated in Fig 3 .

Countries are located in line with the growing importance of the social sector institutional development gap, starting from the smallest. The place of the country in this rating is determined in terms of two components: 1) absolute values of the measuring instruments of the institutional development space; 2) the correlation between these indicators. Lithuania has the highest importance among the analyzed countries. It is due to the harmonious development of all three components of the social sector institutional development in this country. Italy takes second place among the analyzed countries. The absolute values of social infrastructure and social security indices are higher than in Lithuania. However, the development of the social infrastructure in Italy has a higher priority, significantly outweighing the other two components of the social sector. The diagrams in Annex 2 show the calculation results of indicators for other countries. 


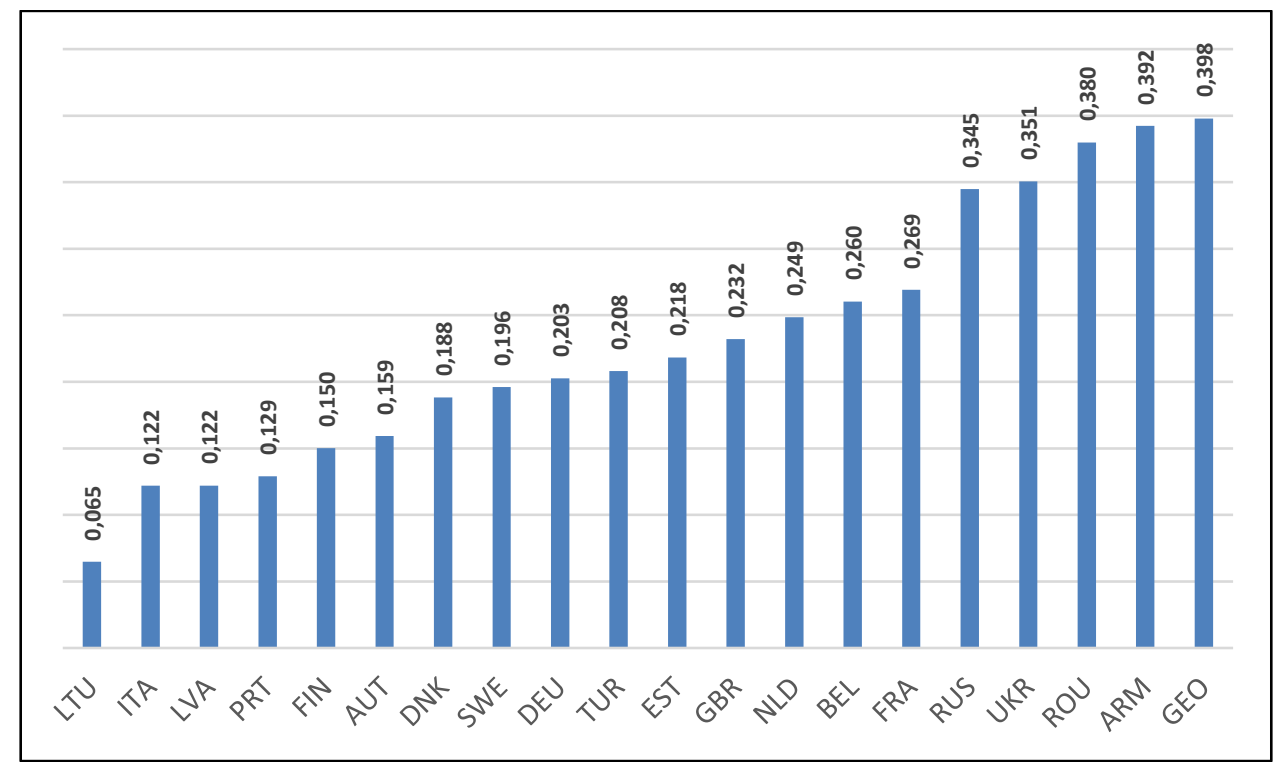

Figure 3. The calculated values of IDGSS

Source: Own elaboration

For economically developed countries from Group 1, the average value of IDGSS is 0.206. They are characterized by the priority of social security development among the social sector institutions. The average index for the group is 0.84 and the level of citizens' social security in these countries is almost the same. The standard deviation of the social security index within the group is at 0.06 and the index of social capital is at one level, at an average of 0.645 (standard deviation of 0.01 ).

Similar trends in the development of social sector institutions are typical for countries from Group II. The value of IDGSS is not much less - 0,1925. The social security provision takes the first place with an average index of 0.78 in the group. There is a diversity between the countries of Northern and Southern Europe. The value of the social security index in the Scandinavian countries is at 0.85-0.91, in Portugal - 0.65. The second place is the development of social capital. The average value of the proper index is 0.649 .

The same level of social capital indicator for the countries of the first and the second group can be explained by the fact that these countries, except for Turkey, are members of the European Union. The harmonization processes of all spheres of socio-economic life, the formation of uniform formal institutions, the perception of universal values in the EU Member States can explain the almost equal importance of the social capital development in these countries. This hypothesis requires additional research beyond the scope of this paper.

The Institutional Development Parity of Social Sector is peculiar for the third group of countries. The average value of the IDGSS in the group is 0.1962 . The common historical and socio-economic conditions for the development of the Baltic countries have determined the close values of the proper indices between the countries. High standard deviation rates for the third group emerge owing to Romania, where social infrastructure and social security indices are significantly lower.

The imbalance in the development of social institutions is typical of the post-Soviet countries. The indicators also differ significantly between countries. Armenia and Georgia have relatively high levels of social infrastructure development, but the values of the social protection index are the lowest among all countries. For Russia and Ukraine, social security is one of the highest priorities, but the indicators of social infrastructure development are the lowest. The value of the IDGSS for the group is almost twice than for other groups of countries. 
INTERDISCIPLINARY APPROACH TO ECONOMICS AND SOCIOLOGY

Table 1 . IDGSS by groups of countries

\begin{tabular}{|c|c|c|c|c|c|c|}
\hline Group & Country & $\begin{array}{l}\text { Country } \\
\text { code }\end{array}$ & $\begin{array}{l}\text { Social Capital } \\
\text { Index }\end{array}$ & $\begin{array}{c}\text { Social } \\
\text { infrastructure } \\
\text { Index } \\
\end{array}$ & $\begin{array}{l}\text { Social Security } \\
\text { Index }\end{array}$ & IDGSS \\
\hline \multirow{6}{*}{ Group 1} & France & FRA & 0,6462 & 0,4198 & 0,8518 & 0,2693 \\
\hline & Germany & $\overline{\mathrm{DEU}}$ & 0,6572 & 0,5290 & 0,8705 & 0,2026 \\
\hline & Italy & ITA & 0,6328 & 0,8533 & 0,7268 & 0,1219 \\
\hline & $\begin{array}{l}\text { United } \\
\text { Kingdom }\end{array}$ & GBR & 0,6447 & 0,4378 & 0,7996 & 0,2320 \\
\hline & \multicolumn{2}{|l|}{ Mean group 1} & 0,6452 & 0,5600 & 0,8122 & 0,2064 \\
\hline & \multicolumn{2}{|c|}{ Standard deviation } & 0,0100 & 0,2013 & 0,0643 & 0,0626 \\
\hline \multirow{10}{*}{ Group 2} & Austria & AUT & 0,6378 & 0,5499 & 0,8073 & 0,1593 \\
\hline & Belgium & BEL & 0,6429 & 0,4010 & 0,7987 & 0,2604 \\
\hline & Denmark & DNK & 0,6961 & 0,5771 & 0,9123 & 0,1882 \\
\hline & Finland & FIN & 0,6966 & 0,5899 & 0,8527 & 0,1502 \\
\hline & Netherlands & NLD & 0,6589 & 0,4293 & 0,8236 & 0,2485 \\
\hline & Portugal & PRT & 0,6289 & 0,4796 & 0,6510 & 0,1290 \\
\hline & Sweden & SWE & 0,7053 & 0,5572 & 0,9076 & 0,1960 \\
\hline & Turkey & TUR & 0,5291 & 0,3150 & 0,4980 & 0,2081 \\
\hline & \multicolumn{2}{|c|}{ Mean group 2} & 0,6494 & 0,4874 & 0,7814 & 0,1925 \\
\hline & \multicolumn{2}{|c|}{ Standard deviation } & 0,0569 & 0,0985 & 0,1405 & 0,0462 \\
\hline \multirow{6}{*}{ Group 3} & Estonia & EST & 0,6229 & 0,4530 & 0,7910 & 0,2182 \\
\hline & Latvia & LVA & 0,5981 & 0,5151 & 0,6960 & 0,1220 \\
\hline & Lithuania & LTU & 0,6003 & 0,5863 & 0,6781 & 0,0649 \\
\hline & Romania & ROU & 0,5667 & 0,1841 & 0,4808 & 0,3798 \\
\hline & \multicolumn{2}{|l|}{ Mean group 2} & 0,5970 & 0,4346 & 0,6615 & 0,1962 \\
\hline & \multicolumn{2}{|c|}{ Standard deviation } & 0,0231 & 0,1757 & 0,1302 & 0,1378 \\
\hline \multirow{7}{*}{ Group 4} & Armenia & ARM & 0,5713 & 0,3163 & 0,2105 & 0,3923 \\
\hline & Georgia & GEO & 0,5474 & 0,4721 & 0,1641 & 0,3978 \\
\hline & Russian & & & & & \\
\hline & Federation & RUS & 0,5511 & 0,2333 & 0,6186 & 0,3449 \\
\hline & Ukraine & UKR & 0,5711 & 0,2100 & 0,4994 & 0,3506 \\
\hline & \multicolumn{2}{|c|}{ Mean group 2} & 0,5602 & 0,3079 & 0,3732 & 0,3714 \\
\hline & \multicolumn{2}{|c|}{ Standard deviation } & 0,0127 & 0,1186 & 0,2209 & 0,0275 \\
\hline
\end{tabular}

Source: Own elaboration

According to the analysis of the IDGSS, one cannot unequivocally assert that its values depend solely on the level of economic development of the country. Only $26.8 \%$ of the total variation in the gap can be explained by economic factors (Figure 4)

The level of its citizens' social security depends directly on the level of the country's economic development. There is a direct correlation between the economic development of the country and the development of social infrastructure. However, the values of the social capital index are practically the same for all countries (Figure 5). Thus, among the analyzed countries, the maximum GDP per capita (the Netherlands - USD 45191,48) exceeds the minimum value of GDP per capita (Armenia - USD 7727.92) by 5.8 times, and SCI values are higher only by $15 \%$ ( 0.659 and 0.571 respectively). The general variability of the social capital index is minimal and stands at 0.05 . It leads to the conclusion that the development of social capital depends much more on non-economic factors. 


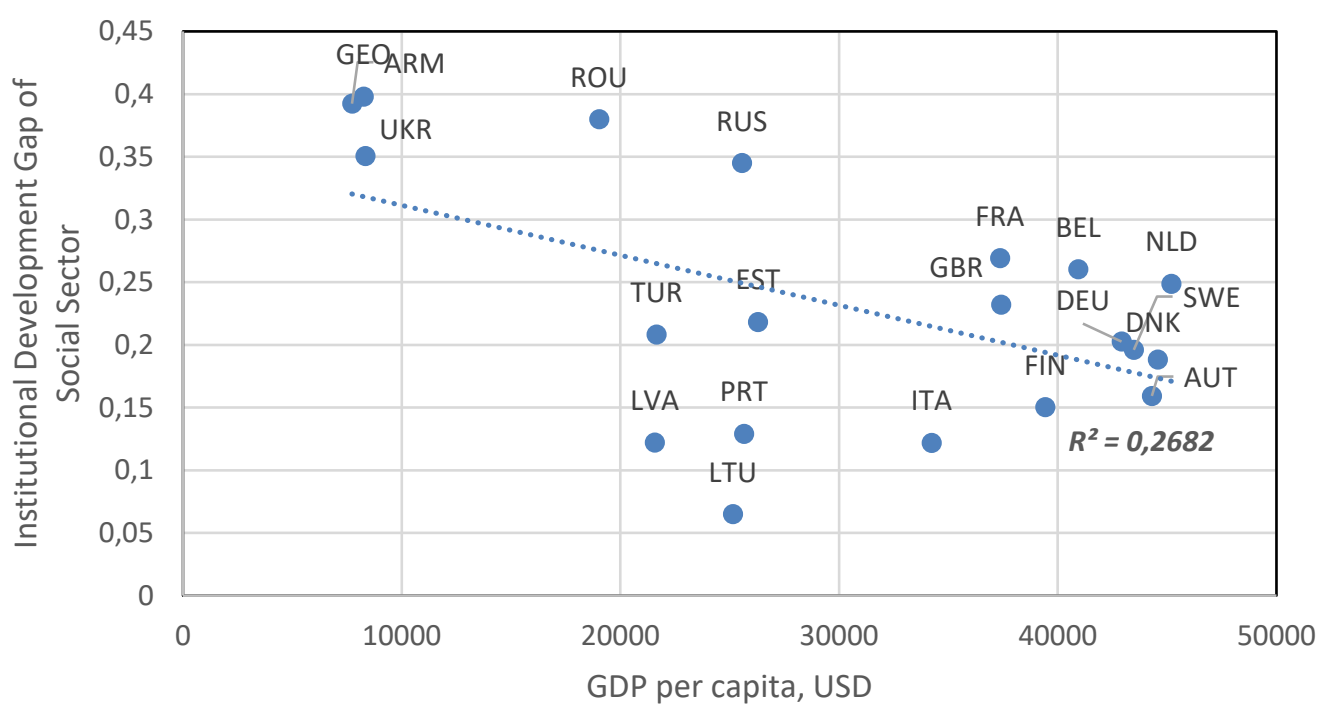

Figure 4. Dependence of IDGSS on the economic development level Source: Own elaboration

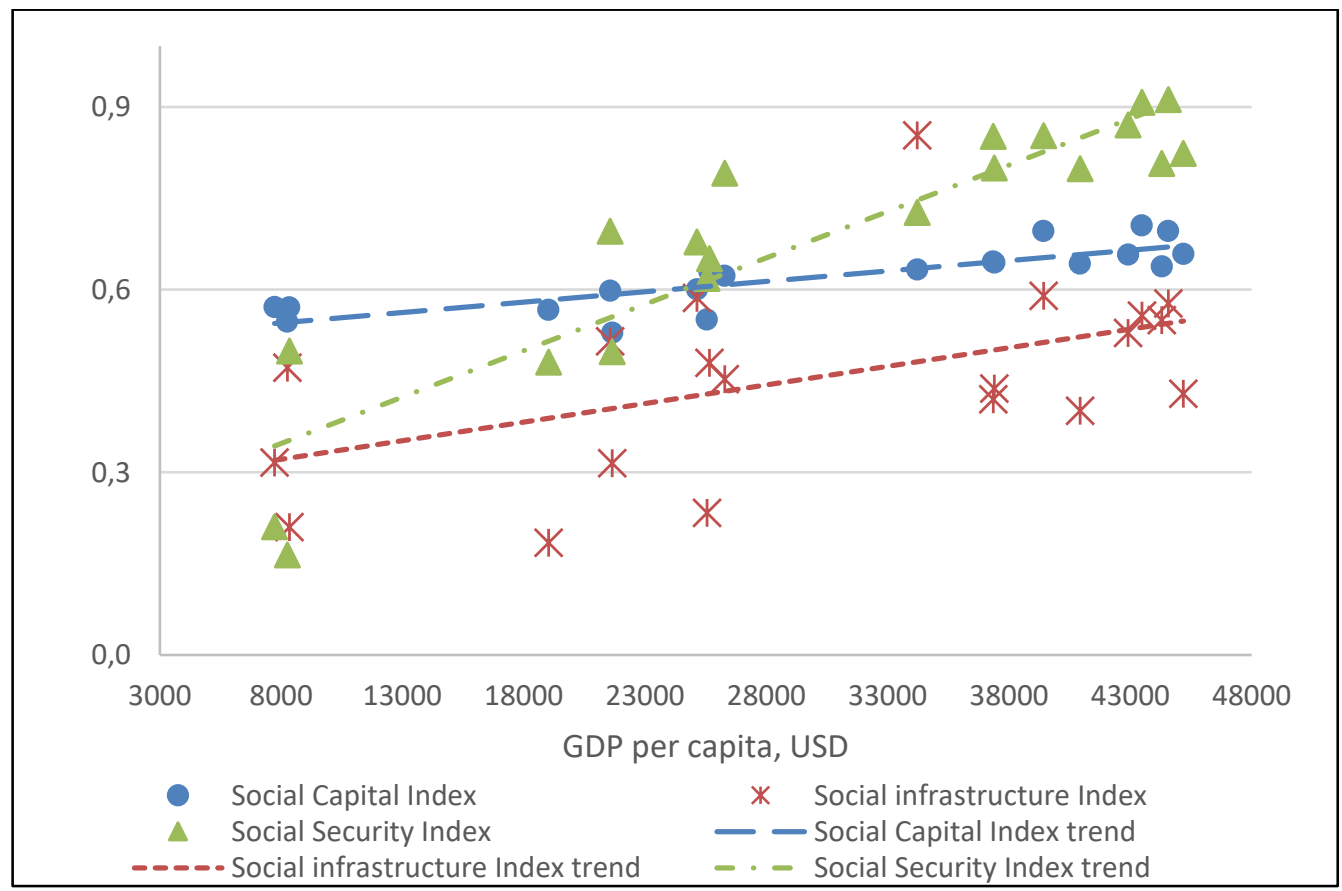

Figure 5. Dependence of IDGSS and its components on the country's economic development level

Source: Own elaboration

We constructed a cross-country regression to evaluate the impact of the factors given in Table empirically to test the hypothesis of a significant effect of non-economic factors on the IDGSS. 
Table 2. Description of independent variables of the regression equation

\begin{tabular}{|c|c|c|}
\hline Factor & Indicator & Abbreviation \\
\hline $\begin{array}{l}\text { Quality of the fundamental } \\
\text { institutions }\end{array}$ & Worldwide Governance Indicators & WGI \\
\hline $\begin{array}{l}\text { The distribution of income among } \\
\text { the citizens of the country }\end{array}$ & Gini coefficient & GINI \\
\hline The level of poverty in the country & $\begin{array}{l}\text { Poverty headcount ratio at } \$ 3.20 \text { a day (2011 } \\
\text { PPP) (\% of the population) }\end{array}$ & Pov320 \\
\hline $\begin{array}{l}\text { The type of institution } \\
\text { establishment } \\
\text { (evolutionary/revolutionary) }\end{array}$ & $\begin{array}{l}\text { Dummy variable: } \\
1-\text { revolutionary } \\
0-\text { evolutionary }\end{array}$ & $\mathrm{EVO}$ \\
\hline $\begin{array}{c}\text { The level of economic } \\
\text { development }\end{array}$ & Logarithm GDP per capita (2011 PPP) & $\ln$ GDP \\
\hline
\end{tabular}

Model, which will be evaluated, is the following:

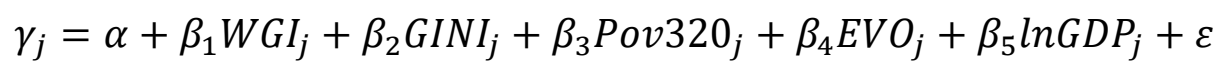

The preliminary analysis confirms the uniformity of the data. Validation of correlation values reveals no multicollinearity of independent variables (the maximum amount was 0.78 correlation between $\ln$ GDP and WGI). The obtained model has a good quality fit.

The evaluations of coefficients and their significance are shown in Table 3.

Table 3. Results of the regression assessment

\begin{tabular}{|c|c|}
\hline VARIABLES & $\gamma$ \\
\hline \multirow[t]{2}{*}{ WGI } & $-0.019 * *$ \\
\hline & $(0.007)$ \\
\hline \multirow[t]{2}{*}{ GINI } & $-0.012 * *$ \\
\hline & $(0.005)$ \\
\hline \multirow[t]{2}{*}{ Poverty320 } & $0.013^{* *}$ \\
\hline & $(0.004)$ \\
\hline \multirow[t]{2}{*}{ evo } & 0.003 \\
\hline & $(0.051)$ \\
\hline \multirow[t]{2}{*}{$\operatorname{lnGDP}$} & 0.110 \\
\hline & $(0.082)$ \\
\hline \multirow[t]{2}{*}{ Constant } & -0.441 \\
\hline & $(0.738)$ \\
\hline Observations & 19 \\
\hline R-squared & 0.651 \\
\hline \multicolumn{2}{|c|}{ Standard errors in parentheses } \\
\hline$* * * \mathrm{p}<0.01, * *$ & $* \mathrm{p}<0.1$ \\
\hline
\end{tabular}

The results show that the impact of the economic development level on the IDGSS cannot be statistically confirmed. The coefficient for the lnGDP indicator is not statistically significant even at the $10 \%$ level. Besides, the value of the gap is not affected by the type of institution formation.

The quality of the fundamental institutions, the uniformity of income distribution, and the poverty level have almost equal impact on the institutional development gap. 


\section{Conclusion}

Authors evaluated the impact of institutions on economic development. In the study, we tried to determine how the development of social sector institutions depends on the country's economic growth. The analysis shows that the various indicators to assess the IDGSS, have different dependencies on the level of economic development. Thus, social capital does not depend on the level of economic development of the country - for four groups of countries the value of social capital is not significantly different - the general variability of the social capital index is minimal and is 0.05 . The conclusions regarding the absence of direct dependence on specific social parameters on the economic development of the country are not abnormal. Canning D. (2012) examined the convergence of health across countries and confirmed the convergence of life expectancy across countries. In many countries, significant progress has been made in healthcare without considerable growth of incomes. On the contrary, social infrastructure and social security demonstrate dependence on the economic development of the country.

The IDGSS depends on non-economic factors, such as the level of development of primary institutions (WGI), the degree of income inequality (Gini ratio) and poverty (the proportion of the population living on less than $\$ 3.2$ per day). All factors show direct dependence.

Thus, the obtained results provide a generalized picture of the heterogeneity of social development between different groups of countries. However, we are aware of the narrowness of our research, which is on the one hand due to the complexity of evaluating institutional quality convergence and, on the other, to the difficulty of distinguishing social sector institutions as a separate institutional structure. An analysis of the literature on the empirics of institutional convergence identifies several limitations and challenges which are in the research:

- narrow data - as a rule, the information about quality is limited both by the list of countries and by the period of observation;

- $\quad$ institutional quality measure - which indicator of the quality of institutions is relevant and can be used in the research of convergence;

- completeness - which institutions should be included in the analysis. There is currently no consensus on this issue. The processes taking place in the structure of economies prove the changing role of the social sector in ensuring economic growth;

- an assessment methodology related to the issues of homogeneity, speed of convergence and general comparability of data. Besides, there is a mutual influence of different institutions, which is also difficult to consider.

The study, conducted within these limitations, does not analyze the dynamics of the quality indicators of institutions, precisely because of the lack of data on the list of countries and the period of observations. However, the gap indicator can be used as an indicator of the social sector institutional quality, since it is based on comprehensive assessments of the institutional space of the social sector: social capital, social infrastructure and social security. The proposed methodology for its evaluation can be used for a more in-depth analysis of institutional convergence. We assumed the mutual influence of measures, but this study does not evaluate this impact. One-way communication takes place. We investigated the effect of economic and non-economic factors on the size of the IDGSS. Although in the context of convergence research, the feedback study is also essential. 


\section{Acknowledgement}

The survey was supported by the Ministry of Education and Science of Ukraine and performed the results of the project "Modeling and forecasting of the socio-economicpolitical road map of reforms in Ukraine for the transition to a sustainable growth model" (registration number 0118U003569).

\section{References}

Abaas, M. S. M., Chygryn, O., Kubatko, O., \& Pimonenko, T. (2018). Social and economic drivers of national economic development: the case of OPEC countries. Problems and Perspectives in Management, 16(4), 155-168. doi:10.21511/ppm.16(4).2018.14.

Acemoglu, D., Johnson, S., Robinson. I., \&Thaicharoen, Y. (2004). Institutional Causes. Macroeconomic Simptoms: Volatility. Crises and Growth. Journal of Monetary Economics, 50, 49-123.

Abu-Hamour, H. M., J. (2018). Synchronous and longitudinal effects of employee commitment on intellectual, social and affective engagement. Business: Theory and Practice, 19, 59-69. https://doi.org/10.3846/btp.2018.07

Acemoglu, D. (2009). Introduction to Modern Economic Growth. Princeton: Princeton University Press. DOI: 10.1016/j.jet.2012.01.023

Antonescu D. (2014). Regional convergence - theoretical approaches. Source MPRA Munich Personal RePEc Archive https://mpra.ub.unimuenchen.de/60288/33/MPRA_paper_60288.pdf

Austin, J. E., Gutiérrez, R., Ogliastri, E., \& Reficco, E. A. (2007) Capitalizing on Convergence. Stanford Social Innovation Review https://ssir.org/articles/entry/capitalizing_on_convergence

Baker, W. (1990). Market Networks and Corporate Behaviour. American Journal of Sociology, 96, 589 - 625. DOI: 10.1086/229573

Balcerzak, A., \& Pietrzak, M. (2015) Quality of Institutions for Global Knowledge-based Economy and Convergence Process in the European Union. Ekonomia nr 42/2015. DOI: http://dx.doi.org/10.17451/eko/42/2015/173

Barro, R.J. (2012). Convergence and Modernization Revisited, NBER Working Paper 18295. DOI: $10.3386 / \mathrm{w} 18295$

Bazo, L, Cukanova, M., Markovicova, L., \& Steinhauser, D. (2019). The Impact of Institutional Environment on Slovak Enterprises and the Institutional Hysteresis Effect. Journal of Competitiveness, 11(3), 35-52. https://doi.org/10.7441/joc.2019.03.03

Bhandari, M.P., \& Bhattarai, K. (2017). Institutional Architecture for Sustainable Development (SD): A Case Study from Bangladesh, India, Nepal, and Pakistan. SocioEconomic Challenges, 1(3), 6-21. DOI: 10.21272sec.1.1(3).6-21.2017

Bilan, Y., Vasilyeva, T., Lyeonov, S., \& Bagmet, K. (2019). Institutional complementarity for social and economic development. Business: Theory and Practice, 20, 103-115. https://doi.org/10.3846/btp.2019.10

Bilan, Y., Lyeonov, S., Vasylieva, T., \& Samusevych, Y. (2018). Does tax competition for capital define entrepreneurship trends in Eastern Europe? Online Journal Modelling the New Europe, (27), 34-66. DOI: 10.24193/OJMNE.2018.27.02

Bilan, Y., Lyeonov, S., Stoyanets, N., \& Vysochyna, A. (2018). The impact of environmental determinants of sustainable agriculture on country food security. International Journal of Environmental Technology and Management, 21(5-6), 289-305. DOI: 10.1504/IJETM.2018.10022294 
Bilan, Y., Vasylieva, T., Lyeonov, S., \& Tiutiunyk, I. (2019). Shadow economy and its impact on demand at the investment market of the country. Entrepreneurial Business and Economics Review, 7(2), 27-43. DOI: 10.15678/EBER.2019.070202

Bilan, Y., Lyeonov, S., Lyulyov, O., \& Pimonenko, T. (2019). Brand management and macroeconomic stability of the country. Polish Journal of Management Studies, 19(2), c. 61-74. DOI: 10.17512/pjms.2019.19.2.05

Brychko, M., \& Semenog, A. (2018.) Efficiency as a new ideology of trust-building corporate governance. Business and Economic Horizons, 14(4), 913-925. http://dx.doi.org/10.15208/beh.2018.62

Buriak, A., Vozňáková, I., Sułkowska, J., \& Kryvych, Y. (2019). Social trust and institutional (Bank) trust: Empirical evidence of interaction. Economics and Sociology, 12(4), 116129. DOI: $10.14254 / 2071-789 X .2019 / 12-4 / 7$

Bilan, Y., Brychko, M., Buriak, A., \& Vasilyeva, T. (2019). Financial, business and trust cycles: The issues of synchronization. Zbornik Radova Ekonomskog Fakultet au Rijeci. 37(1), 113-138. DOI: 10.18045/zbefri.2019.1.113

Canning D. (2012). Progress in Health Around the World. Journal of Developemnt Studies, 48(12), 1784-1798. https://doi.org/10.1080/00220388.2012.663907

Casey S. (2005). Establishing standards for social infrastructure. Ipswich, Qld : UQ Boilerhouse, Community Engagement Centre

Claridge, T. (2004). Social Capital and Natural Resource Management: An important role for social capital? Unpublished Thesis, University of Queensland, Brisbane, Australia. https://doi.org/10.5172/rsj.351.15.2.119

Cyrek, M. (2019). Government social spending in the EU countries: efficiency in poverty and income inequality reduction. Equilibrium. Quarterly Journal of Economics and Economic Policy, 14(3), 405-424. https://doi.org/10.24136/eq.2019.019

Dirzyte, A.; Rakauskienè, O. G.; Servetkiené, V. 2017. Evaluation of resilience impact on socio-economic inequality. Entrepreneurship and Sustainability Issues, 4(4), 489501. https://doi.org/10.9770/jesi.2017.4.4(7).

Djalilov, K., Lyeonov, S., \& Buriak, A. (2015). Comparative studies of risk, concentration and efficiency in transition economies. Risk Governance and Control: Financial Markets and Institutions, 5(4CONT1), 178-187. DOI:10.22495/rgcv5i4c1art7

Dmytrów, K., \& Bieszk-Stolorz, B. (2019). Mutual relationships between the unemployment rate and the unemployment duration in the Visegrad Group countries in years 20012017. Equilibrium. Quarterly Journal of Economics and Economic Policy, 14(1), 129148. https://doi.org/10.24136/eq.2019.006

Dovhan Z., Kravchuk I., \& Karaś P. (2017). The financial instruments market - an institutional approach. Financial markets, institutions and risks, 1(1), 22-28. DOI:10.21272/fmir.1(1).22-28.2017

Fukuyama, F. (1995). Trust : the social virtues and the creation of prosperity. London: Hamish Hamilton.

Ginevicius, R. (2019). Quantitative Assessment of the Compatibility of the Development of Socioeconomic Systems. Journal of Competitiveness, 11(2), 3650. https://doi.org/10.7441/joc.2019.02.03

Ginevičius, R., Gedvilaitè, D., Stasiukynas, A., Čepel, M. (2018). Integrated Assessment of the Socioeconomic Systems' Development. Economics and Sociology, 11(1), 11-21. doi:10.14254/2071-789X.2018/11-1/1

Gowdy H., Hildebrand A., La Piana D., \& Mendes Campos M. (2009). Convergence. How Five Trends Will Reshape the Social Sector. Focus. The James Irvine Foundation. https://www.irvine.org. 
Gruševaja, M., \& Pusch T. (2015). Institutional Convergence of CEECs and its Connection to Growth and Cohesion, GRINCOH Working Paper Series, Paper No. $7.01 \mathrm{http}: / / \mathrm{www}$. grincoh.eu/media/serie_7_institutional_convergence/grincoh_wp7.01 _grusevaja_pusch.pdf. DOI: 10.13140/RG.2.1.2053.8964

Grenčíková, A., Bilan, Y., Samusevych, Y., \& Vysochyna, A. (2019). Drivers and inhibitors of entrepreneurship development in central and eastern European countries. Proceedings of the 33rd International Business Information Management Association Conference, IBIMA 2019: Education Excellence and Innovation Management through Vision 2020. c. 2536-2547

Mishchuk, H., Samoliuk, N., \& Bilan, Y. (2019). Measuring social justice in the light of effectiveness of public distributive policy. Administratie si Management Public, (32), 63-76. DOI: 10.24818/amp/2019.32-05.

Halaskova, R. (2018). Structure of General Government Expenditure on Social Protection in the EU Member States. Montenegrin Journal of Economics, 14(4), 7-21. DOI: 10.14254/1800-5845/2018.14-4.1

Harshad, D. (2017a). An Inquiry on Social issues - Part 1. Business Ethics and Leadership, $1(2), 78-87$.

Harshad, D. (2017b). An Inquiry on Social Issues - Part 2. Business Ethics and Leadership, 1(3), 45-63.

Hitka, M., Kozubíková, L., \& Potkány, M. (2018). Education and gender-based differences in employee motivation. Journal of Business Economics and Management, 19(1), 80-95. https://doi.org/10.3846/16111699.2017.1413009

Humbatova, S. I., \& Hajiyev, N. G. (2019). The role of spending on education and science in sustainable development. Entrepreneurship and Sustainability Issues, 7(2), 17041727. https://doi.org/10.9770/jesi.2019.7.2(63)

Iacobuta, A. O., Mursa, G. C., Mihai, C., Cautisanu, C., \& Cismas, L. M. (2019). Institutions and sustainable development: a cross-country analysis. Transformations in Business \& Economics, 18(2a) (47a).

Inglehart, R. (1997). Modernization and post-modernization: cultural, economic and political change in 43 societies. Princeton: Princeton University Press.].

International institute of Social Studies. (n.d.). http://www.indsocdev.org/home.html

Khorakian, A., \& Jahangir. M. (2018). The impact of social network on the innovative behavior of it professionals: what is the role of sharing mistakes? E+M Ekonomie a Management, 21(3). https://dx.doi.org/10.15240/tul/001/2018-3-012

Kliestik, T., Misankova, M., Valaskova, K., \& Svabova, L. (2018). Bankruptcy prevention: new effort to reflect on legal and social changes. Science and Engineering Ethics, 24(2), 791-803.

Ko, H., \& Min, K. (2019). Determinants of social expenditures in post-socialist countries. Economics and Sociology, 12(2), 253-264. doi:10.14254/2071- 789X.2019/12-2/15

Kobylińska, U., Rollnik-Sadowska, E., \& Samul, J. (2017). Young people on the labour market in Poland - the point of view of the employer. Oeconomia Copernicana, 8(4), 553-568. https://doi.org/10.24136/oc.v8i4.34

Kolosok, S., \& Myroshnychenko, I. (2015) Structural change and business cycle dynamics in transition economies. Journal of Applied Economic Sciences, 10(1), 128-141.

Kostel, M., Leus, D., Cebotarenco, A., \& Mokrushina, A. (2017). The Sustainable Development Goals for Eastern Partnership Countries: Impact of Institutions. SocioEconomic Challenges, 1(3), 79-90. DOI: 10.21272sec.1.1(3).7990.2017.

Kostyuchenko, N., Starinskyi, M., Tiutiunyk, I., \& Kobushko, I. (2018). Methodical approach to the assessment of risks connected with the legalization of the proceeds of crime. 
Montenegrin Journal of Economics, 14(4), 023-043. DOI: 10.14254/18005845/2018.14-4.2

López-Tamayo, J., Ramos, R., \& Suriñach, J. (2014) Institutional and Socio-Economic Convergence in the European Union. Croatian Economic Survey, 16(2), 5-28. DOI: 10.115179/ces.16.2.1

Lewandowska-Gwarda, K. (2018). Female unemployment and its determinants in Poland in 2016 from the spatial perspective. Oeconomia Copernicana, 9(2), 183-204. https://doi.org/10.24136/oc.2018.010

Leonov, S.V., Vasylieva, T.A., \& Tsyganyuk, D.L. (2012). Formalization of functional limitations in functioning of co-investment funds basing on comparative analysis of financial markets within FM CEEC. Actual Problems of Economics, 134(8), 75-85

Leonov, S., Frolov, S., \& Plastun, V. (2014) Potential of institutional investors and stock market development as an alternative to households' savings allocation in banks. Economic Annals-XXI , 11-12, 65-68.

Maknickienė, N., Lapinskaitè, I., Miečinskienė, A., \& Skačkauskienė, I. (2018). Patterns of inequality of Lithuanian regions. Journal of Business Economics and Management, 19(2), 323-342. https://doi.org/10.3846/jbem.2018.5574

Melnyk, L., Taraniuk, L., Kozmenko, O., \& Sineviciene, L. (2017). Influence of the minimum salary level increase on the business entities activity in the context of transition to the sustainable development. Problems and Perspectives in Management, 15(1), 72-79. DOI: $10.21511 / \mathrm{ppm} .15(1) .2017 .07$

Menshikov, V., \& Volkova, O. (2018). Economic growth and impact of institutions on quality of human capital: a case study, Journal of Security and Sustainability Issues, 8(2), 247 256. https://doi.org/10.9770/jssi.2018.8.2(11)

Mentel, G., Vasilyeva, T., Samusevych, Y., \& Pryymenko, S. (2018). Regional differentiation of electricity prices: Social-equitable approach. International Journal of Environmental Technology and Management, 21(5-6), 354-372. DOI: 10.1504/IJETM.2018.100583

Migala-Warchol, A., \& Pasternak-Malicka, M. (2018). Living Standards of EU Countries' Residents: Impact of Education and Innovation. Marketing and Management of Innovations, 4, 307-315. http://doi.org/10.21272/mmi.2018.4-26.

Mursa, G. C., Iacobuta, A. O., Socoliuc, O. R., Clipa, R. I., \& Butiseaca, A. (2018). Youth unemployment among eu countries - a challenge for sustainable growth and social cohesion. Transformations in Business \& Economics, 17(2b) (44b).

Niroomand, F., \& Nissan, E. (2007). Socio-Economic Gaps within the EU: A Comparison, International Advances in Economic Research, Springer; International Atlantic Economic Society, 13(3), 365-378. DOI: 10.1007/s11294-007-9092-0

Northern Ireland Assembly. (2017). Potential of social infrastructure investment to enhance social development and economic growth in Northern Ireland. Knowledge Exchange Seminar Series 2016-17. http://www.niassembly.gov.uk/globalassets/documents/raise/knowledge_exchange/brief ing_papers/series6/mcclements231116.pdf

Novák, V., Vokoun, M., Stellner, F., \& Vochozka, M. (2016). Institutional analysis of the contemporary regional labour market in the Czech Republic. E+M Ekonomie a Management. Volume 19, Issue 3. p. 4-19. DOI: 10.15240/tul/001/2016-3-001

Oh, J. H., Lee, Y. M., \& Shim, J. H. (2017). Preparing ageing workers for the future: implication for facilitating middle-aged workforce following the decline of working age population in Korea. International Journal of Economic Policy in Emerging Economies (IJEPEE), Vol. 10, No. 3. DOI: 10.1504/IJEPEE.2017.086625 
Pacáková, V., \& Kopecká, L. (2018). Comparing inequalities in health outcomes in European countries. Journal of International Studies, 11(4), 215-227. doi:10.14254/20718330.2018/11-4/15

Poliakh S., \& Alikariyev N. (2017). Evaluation Quality of Consumer Protection by Financial Markets Services. Financial Markets, Institutions and Risks, 1(3), 75-81. DOI: 10.21272/fmir.1(3).75-81.2017

Ravallion, M. (2012). Why Don't We See Poverty Convergence. American Economic Review, 102(1), 504-523. DOI: 10.1257/aer.102.1.504

Rodríguez-Pose, A., \& Tselios, V. (2013) Toward Inclusive Growth: Is There Regional Convergence in Social Welfare?, International Regional Science Review, forthcoming. http://dx.doi.org/10.1177/0160017613505201

Rodrik, D. (2011). The Future of Economic Convergence, NBER Working Paper 17400. DOI: $10.3386 / \mathrm{w} 17400$

Rodrik D. (2013). Unconditional Convergence in Manufacturing, Quarterly Journal of Economics, 128(1), 165-204. https://doi.org/10.1093/qje/qjs047

Roman Dennis Bausch. (2019). Social capital and the cyclicality of government expenditure. International Journal of Trade and Global Markets (IJTGM), 12(3/4). DOI: 10.1504/IJTGM.2019.101545

Sadiqi, J. (2018). Evaluating the development of SMART communities: a public value perspective. Marketing and Management of Innovations, 2, 155-157. http://doi.org/10.21272/mmi.2018.2-13

Savoia A. and Sen K. Do We See Convergence in Institutions? A CrossCountry Analysis. Development Economics and Public Policy Working Paper Series WP No. 33/2012 http://hummedia.manchester.ac.uk/institutes/gdi/publications/workingpapers/depp/depp _wp33.pdf https://doi.org/10.1080/00220388.2015.1060315

Shpak, N., Satalkina, L., Sroka, W., \& Hittmar, S. (2017). The social direction of enterprises' innovation activity. Polish Journal of Management Studies; 16 (1), 187-201. DOI: 10.17512/pjms.2017.16.1.16

Skačkauskienè, I., \& Bytaute, S. (2012). Social capital definition and measurement problems. Business: Theory and Practice, 13(3), 208-216. https://doi.org/10.3846/btp.2012.22

Sokolenko, L.F., Tiutiunyk, I.V., \& Leus, D.V. (2018). Ecological and economic security assessment in the system of regional environmental management: A case study of Ukraine. International Journal of Ecology and Development. 32(3), 27-35

Smirnov, A., Lavrinenko, O., Ohotina, A., Shmarlouskaya, H., \& Betlej, A. (2019). Assessment of convergence processes of social-economic security indicators in Latvian municipalities, Journal of Security and Sustainability Issues, 9(2), 663674. https://doi.org/10.9770/jssi.2019.9.2(23)

Sułkowski, Ł., Seliga, R., \& Woźniak, A. (2019a). Strategic Challenges of Mergers and Acquisitions in the Higher Education Sector. Entrepreneurial Business and Economics Review, 7(2), 199-215.

Sulkowski, L., Wozniak, A., \& Seliga, R. (2019b). Organizational identity of university in merger process. Economic and Social Development: Book of Proceedings, 756-762.

Sungeun Cho, \& Young-Min Lee. (2018). Downgrading employment of university graduates in Korea and policy implications. International Journal of Economic Policy in Emerging Economies (IJEPEE), 11(3). DOI: 10.1504/IJEPEE.2018.093948

Valaskova, K., Kliestik, T., \& Kovacova, M. (2018). Management of financial risks in Slovak enterprises using regression analysis. Oeconomia Copernicana, 9(1),105-121.

Vargas-Hernández, J. G., Orozco-Quijano, E. P., \& Virchez, J. (2018). Critical Analysis On Institutional Capital On Trade And Environmentally Sustainable Development Under 
NAFTA. SocioEconomic

Challenges,

$4(2)$,

21-31.

DOI: http://doi.org/10.21272/sec.2(4).21-31.2018

Vasilyeva, T., Lyeonov, S., Adamičková, I., \& Bagmet, K. (2018). Institutional Quality of Social Sector: the Essence and Measurements. Economics and Sociology, 11(2), 248262. DOI: $10.14254 / 2071-789 X .2018 / 11-2 / 17$

Vasylyeva, T.A., \& Pryymenko, S.A. (2014). Environmental economic assessment of energy resources in the context of ukraine's energy security. Actual Problems of Economics, $160(1)$, c. $252-260$

Vasylyeva, T.A., Leonov, S.V., \& Lunyakov, O.V. (2014). Countercyclical capital buffer as a macroprudential tool for regulation of the financial sector. Actual Problems of Economics. 158(8), 278-283.

Vasilyeva, T.A., Leonov, S.V., \& Lunyakov, O.V. (2013). Analysis of internal and external imbalances in the financial sector of Ukraine's economy. Actual Problems of Economics, 150(12), 176-184.

Vasylieva, T., Lyulyov, O., Bilan, Y., \& Streimikiene, D. (2019). Sustainable economic development and greenhouse gas emissions: The dynamic impact of renewable energy consumption, GDP, and corruption. Energies, 12(17), 3289. DOI 10.3390/en12173289

Veri, J., Ridwan, M., \& Lasman, F. (2019). Employee behaviours affecting job satisfaction. International Journal of Trade and Global Markets (IJTGM), Vol. 12, No. 3/4. https://doi.org/10.1504/IJTGM.2019.101559

Yevdokimov, Y., Melnyk, L., Lyulyov, O., Panchenko, O., \& Kubatko, V. (2018). Economic freedom and democracy: Determinant factors in increasing macroeconomic stability. Problems and Perspectives in Management, 16(2), 279-290. DOI: 10.21511/ppm.16(2).2018.26

Žofčinová, V. (2017). Factors influencing the provision of social welfare services at the level of territorial self-government of the Slovak Republic. Administratie si Management Public, (29), 27-40. 
INTERDISCIPLINARY APPROACH TO ECONOMICS AND SOCIOLOGY

\section{Annex 1 - Data description}

\begin{tabular}{|c|c|c|c|}
\hline $\begin{array}{l}\text { Measures/ } \\
\text { index }\end{array}$ & Indicator & Description & Data source \\
\hline \multirow{6}{*}{ 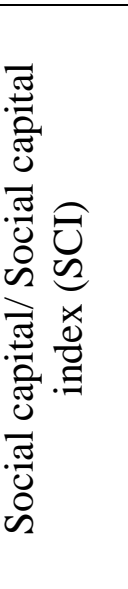 } & Civic Activism & Measures use of media and protest behaviour & $\begin{array}{l}\text { World Development } \\
\text { Indicators, accessed at } \\
\text { http://www.IndSocDev.org/ }\end{array}$ \\
\hline & Clubs and Associations & Defined as membership in local voluntary associations & $\begin{array}{l}\text { World Development } \\
\text { Indicators, accessed at } \\
\text { http://www.IndSocDev.org/ }\end{array}$ \\
\hline & Intergroup Cohesion & Measures ethnic and sectarian tensions, and discrimination & $\begin{array}{l}\text { World Development } \\
\text { Indicators, accessed at } \\
\text { http://www.IndSocDev.org/ }\end{array}$ \\
\hline & $\begin{array}{l}\text { Interpersonal Safety and } \\
\text { Trust }\end{array}$ & $\begin{array}{l}\text { Focuses on perceptions and incidences of crime and personal } \\
\text { transgressions }\end{array}$ & $\begin{array}{l}\text { World Development } \\
\text { Indicators, accessed at } \\
\text { http://www.IndSocDev.org/ }\end{array}$ \\
\hline & Gender Equality & Reflects gender discrimination in home, work and public life & $\begin{array}{l}\text { World Development } \\
\text { Indicators, accessed at } \\
\text { http://www.IndSocDev.org/ }\end{array}$ \\
\hline & Inclusion of Minorities & $\begin{array}{l}\text { Measures levels of discrimination against vulnerable groups } \\
\text { such as indigenous peoples, migrants, refugees, or lower caste } \\
\text { groups }\end{array}$ & $\begin{array}{l}\text { World Development } \\
\text { Indicators, accessed at } \\
\text { http://www.IndSocDev.org/ }\end{array}$ \\
\hline \multirow{8}{*}{ 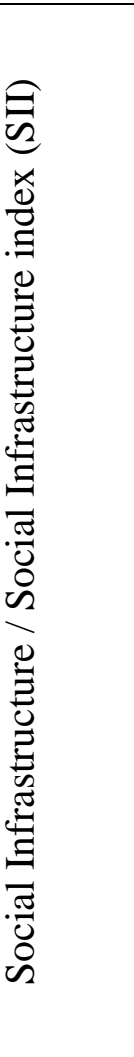 } & $\begin{array}{l}\text { Hospital beds (per } 1,000 \\
\text { people) }\end{array}$ & $\begin{array}{l}\text { Hospital beds include inpatient beds available in public, } \\
\text { private, general, and specialized hospitals and rehabilitation } \\
\text { centres. In most cases beds for both acute and chronic care are } \\
\text { included. }\end{array}$ & World Health Organization, \\
\hline & $\begin{array}{l}\text { General paediatricians, } \\
\text { per } 100000 \text { population }\end{array}$ & $\begin{array}{l}\text { Paediatricians deal with the development, care, and diseases of } \\
\text { children. (per 100,000 population) Exclusion - Paediatric } \\
\text { specialties (e.g. child psychiatry, child/paediatric surgery, } \\
\text { child/paediatric gynaecology, paediatric cardiology, paediatric } \\
\text { oncology, etc.) }\end{array}$ & $\begin{array}{l}\text { WHO European Data } \\
\text { Warehouse }\end{array}$ \\
\hline & $\begin{array}{l}\text { Psychiatrists, per } 100000 \\
\text { population }\end{array}$ & $\begin{array}{l}\text { Psychiatrists are medical doctors who specialise in the } \\
\text { prevention, diagnosis and treatment of mental illness. } \\
\text { Exclusion - - Psychologists }\end{array}$ & $\begin{array}{l}\text { WHO European Data } \\
\text { Warehouse }\end{array}$ \\
\hline & $\begin{array}{l}\text { Computed Tomography } \\
\text { Scanners, per } 100000 \\
\text { population }\end{array}$ & Number of Computed Tomography scanners (CT units). & $\begin{array}{l}\text { WHO European Data } \\
\text { Warehouse }\end{array}$ \\
\hline & $\begin{array}{l}\text { Magnetic Resonance } \\
\text { Imaging Units, per } 100 \\
000 \text { population }\end{array}$ & Number of Magnetic Resonance Imaging units (MRI units). & $\begin{array}{l}\text { WHO European Data } \\
\text { Warehouse }\end{array}$ \\
\hline & $\begin{array}{l}\text { Gross enrolment ratio, } \\
\text { primary to tertiary, both } \\
\text { sexes }(\%)\end{array}$ & $\begin{array}{l}\text { Total enrollment in primary, secondary and tertiary education, } \\
\text { regardless of age, expressed as a percentage of the total } \\
\text { population of primary school age, secondary school age, and } \\
\text { the five-year age group following on from secondary school } \\
\text { leaving. GER can exceed } 100 \% \text { due to the inclusion of over- } \\
\text { aged and under-aged students because of early or late school } \\
\text { entrance and grade repetition. }\end{array}$ & $\begin{array}{l}\text { UNESCO Institute for } \\
\text { Statistics }\end{array}$ \\
\hline & $\begin{array}{l}\text { Expenditure on education } \\
\text { as } \% \text { of total government } \\
\text { expenditure }(\%)\end{array}$ & $\begin{array}{l}\text { Total general (local, regional and central) government } \\
\text { expenditure on education (current, capital, and transfers), } \\
\text { expressed as a percentage of total general government } \\
\text { expenditure on all sectors (including health, education, social } \\
\text { services, etc.). }\end{array}$ & $\begin{array}{l}\text { UNESCO Institute for } \\
\text { Statistics }\end{array}$ \\
\hline & $\begin{array}{l}\text { Duration of compulsory } \\
\text { education (years) }\end{array}$ & $\begin{array}{l}\text { Number of years that children are legally obliged to attend } \\
\text { school. }\end{array}$ & $\begin{array}{l}\text { UNESCO Institute for } \\
\text { Statistics }\end{array}$ \\
\hline \multirow{4}{*}{ 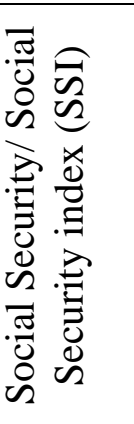 } & $\begin{array}{l}\text { Unemployment (\% of the } \\
\text { number of employees) } \\
\text { unemploy }\end{array}$ & The percent of people in working age who are out of work. & $\begin{array}{l}\text { World Development } \\
\text { Indicators }\end{array}$ \\
\hline & $\begin{array}{l}\text { Adolescent fertility (The } \\
\text { number of births per } \\
1,000 \text { women aged } 15-19)\end{array}$ & $\begin{array}{l}\text { The number of births among women aged } 15-19 \text { years (per } \\
1000 \text { women). }\end{array}$ & $\begin{array}{l}\text { World Development } \\
\text { Indicators }\end{array}$ \\
\hline & $\begin{array}{l}\text { Age dependence ( } \% \text { of the } \\
\text { number of working-age } \\
\text { population) }\end{array}$ & $\begin{array}{l}\text { The number of people under the age of } 15 \text { years and after } 64 \\
\text { years in relation to the number of people aged } 15 \text { to } 64 \text { years. } \\
\text { The values are given in the proportion of age-dependent } \\
\text { people of working age (per } 100 \text { people). }\end{array}$ & $\begin{array}{l}\text { World Development } \\
\text { Indicators }\end{array}$ \\
\hline & $\begin{array}{l}\text { Unprotected (vulnerable) } \\
\text { employment (\% of the } \\
\text { number of employees) }\end{array}$ & $\begin{array}{l}\text { The number of employees in the areas sensitive to changes in } \\
\text { the business cycle (self-employed persons or employed in the } \\
\text { household). }\end{array}$ & $\begin{array}{l}\text { World Development } \\
\text { Indicators }\end{array}$ \\
\hline
\end{tabular}


Annex 2

Legend

---- - average for the group of countries - data of the concrete country

Group 1

France

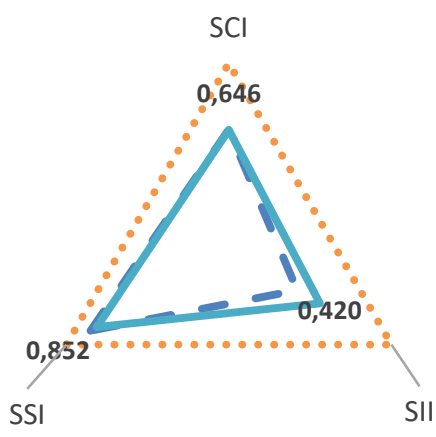

Italy

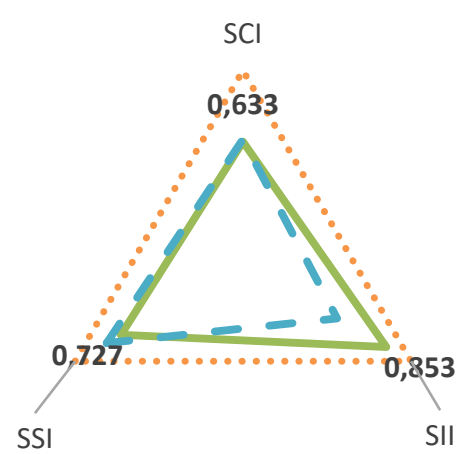

Germany

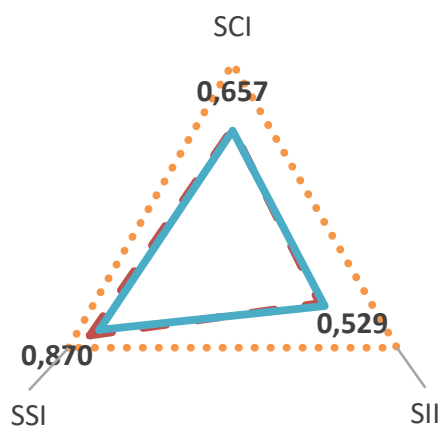

United Kingdom

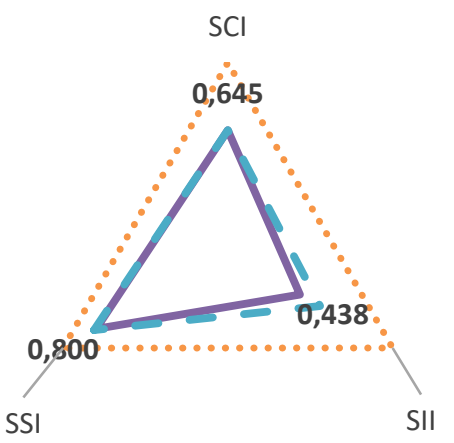




\section{Group 2}

Austria

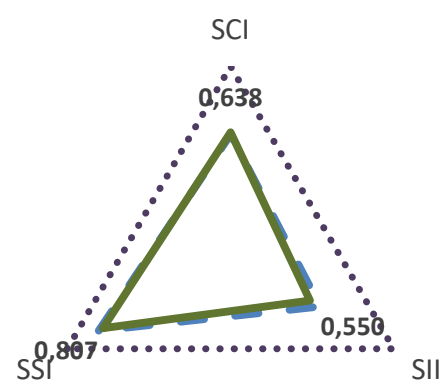

Denmark

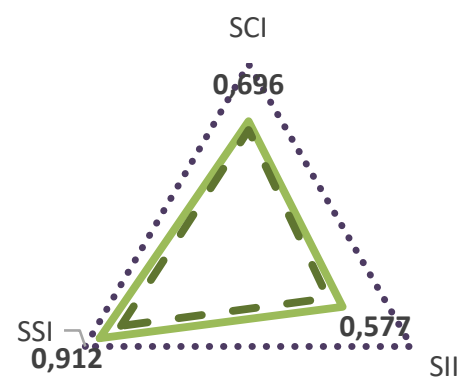

Netherlands

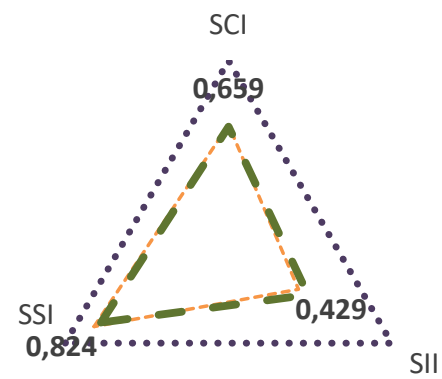

Sweden

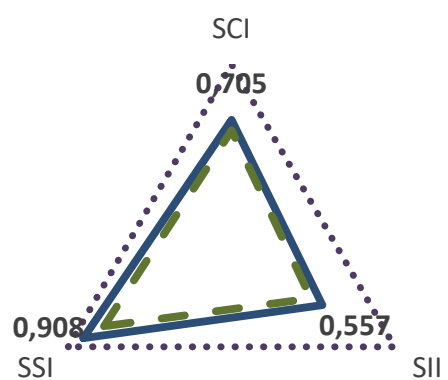

Belgium

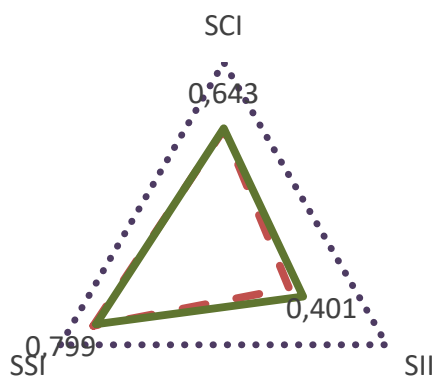

Finland

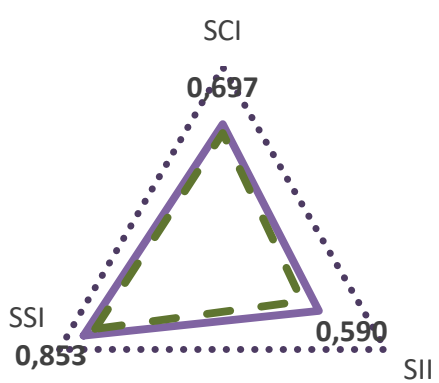

Portugal

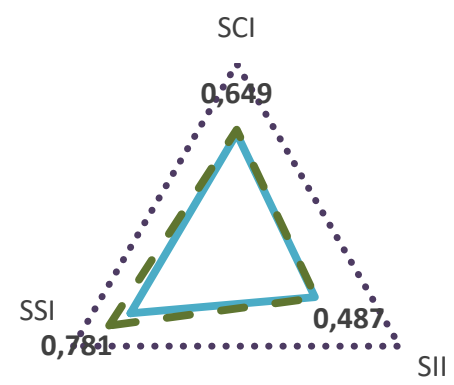

Turkey

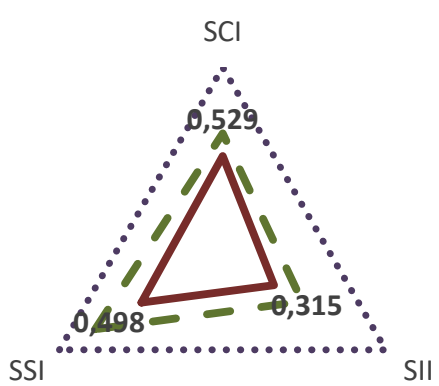




\section{Group 3}

Estonia

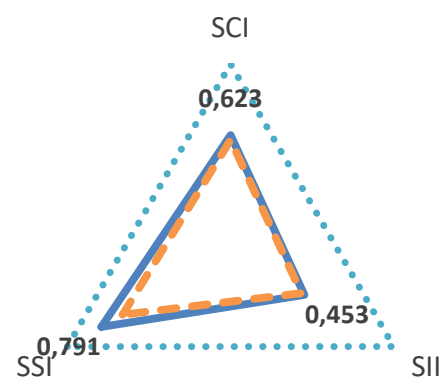

Lithuania

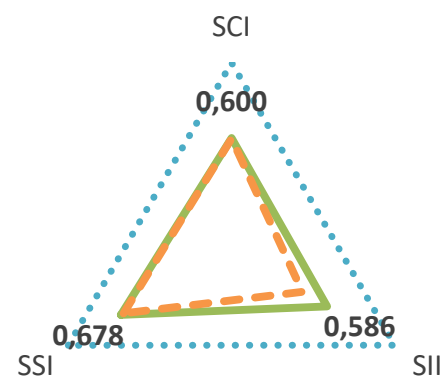

\section{Group 4}

Armenia

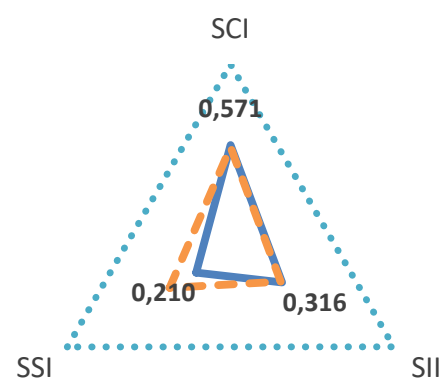

Russian Federation

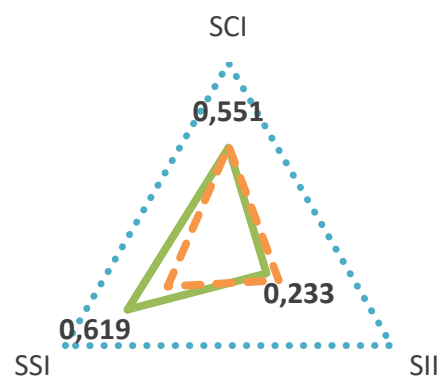

Latvia

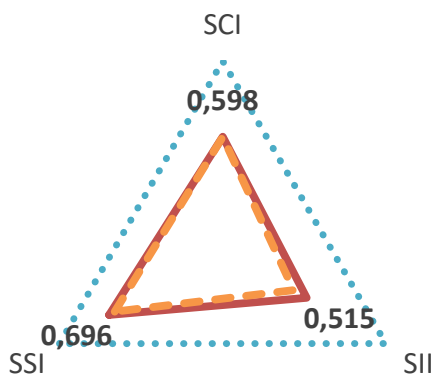

Romania

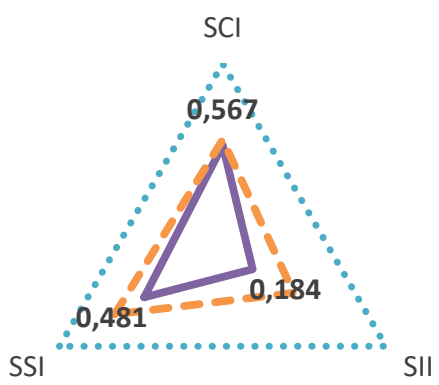

Georgia

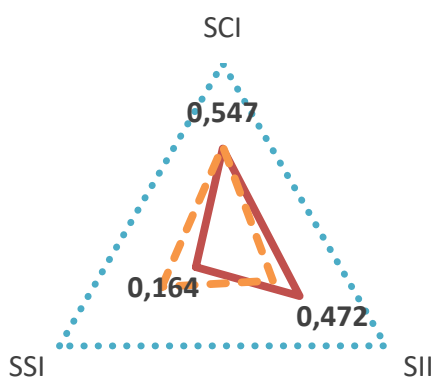

Ukraine

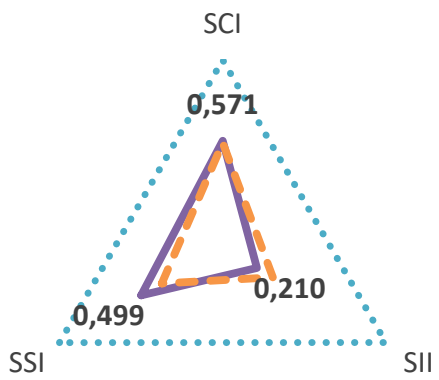

